\title{
The Multisystemic Effect of Oestradiol Variations
}

\author{
ELENA MIHALCEANU ${ }^{1}$, ALINA MIHAELA CALIN²*, MIHAELA DEBITA2*, DRAGOS NEGRU³, GETA MITREA2*, IRINA NEGRU \\ ${ }^{1}$ Grigore T. Popa University of Medicine and Pharmacy, Faculty of Medicine, Mother and Child Department, 16 University Str., \\ 16,700115, lasi, Romanial \\ ${ }^{2}$ Dunarea de J0s, University of Medicine and Pharmacy, Faculty of Medicine,47 Domneasca Str., 800008, Galati, Romania \\ ${ }^{3}$ Grigore T. Popa University of Medicine and Pharmacy, Faculty of Medicine, I-st Surgical Department, 16 University Str., \\ 16,700115 , Iasi, Romania
}

\begin{abstract}
Ovarian hormones are: oestrogenic hormone, also known as follicular hormone or female sexual hormone orchemically oestradiol; yellow body hormone, progestin or, chemically, progesterone. Oestrogenic hormone is particularly involved in the first part of the oestrus period, and the yellow body hormone in the second part (pseudo-pregnancy) and in the gestation state; the third ovarian hormone, known as relaxin, was isolated from the yellow body. Oestrogens are responsible for the development of female secondary features. Together with progesterone it controls the most important female reproductive processes. The most biologically active of oestrogens is 17b-oestradiol. Oestradiol is produced by ovarian follicles, testicles, but also by some organs such as the liver, adrenal glands, mammary glands and the brain. Oestradiol activates two specific nuclear proteins, oestrogen receptors alpha (ERá) and oestrogen receptors beta (Erâ). Oestrogen receptors alpha are predominant in the mammary gland, genital apparatus, bone, nervous and cardiovascular system. Oestrogen receptors beta are found in the uterus, monocytes, tissue macrophages, colon and lung epithelial cells, epithelial cells of the prostate. The main actions of oestradiol are: endometrial proliferation, effects on the vagina and the mammary gland; italso has a role in preventing osteoporosis and reducing cardiovascular risk. Oestradiol is primarily produced in the ovary (the follicle, yellow body), but small amounts are also formed in the testicles and the cortex of the adrenals. In pregnancy, oestrogen is mainly produced by the placenta. Approximately $98 \%$ of oestradiol is linked to sex hormone binding globulin (SHBG). The level of oestradiol increases throughout the follicular phase of the menstrual cycle in close dependence with the growth and development of the ovarian follicle. For the determination of oestradiol, we conducted a study of 64 people, of which 47 women (73.43\% and 17 men (26.57\%). The presence of oestrogen receptors alpha indicates an increased risk of breast cancer. Breastcancer is hormone dependent, 74\% of cases are oestrogenpositive receptors, and $30 \%$ of cases are progesterone-positive receptors. The main reason for the development of hyperplasia is the increase in oestrogen levels.
\end{abstract}

Keywords: ovarian hormones, oestradiol, progesterone, oestrogen receptors, hydronephrosis

Evidence obtained through ovariectomy and transplantation experience clearly showed that the ovary produces an internal secretion responsible for the sexual development of the female; however, the results of experiments with ovarian extracts have not been conclusive until Allen and Doisy's work in 1923. They obtained an active ethereal extract from the aspirated follicular fluid of the hedgehog female ovary, an extract that could cause oestrus in animals not having reached puberty. The success of these researchers was largely due to the use of a precise method for highlighting oestrogen, namely the technique of vaginal secretion research. The name of estrone for this ovarian hormone was proposed by Parkes and Bellerby.

Its presence in high concentration in the follicular fluid and the fact that follicular maturation coincides with the onset of the oestrus make follicular cells to be considered as the main source.

However, these cells may notbe the only one responsible because Parkes showed that the oestrus continues at regular intervals after the follicles have been completely destroyed by X-rays; moreover, the hormone can be extracted exclusively from the ovary stroma. Interstitial cells may in this situation be a place of origin for the hormone. One of the most distinguished characteristics of this hormone is its very wide spread in animal tissues. This one or an oestrogen-like hormone with similar action is found in the blood, muscle and urine of females, both pregnant and non-pregnant, in the urine of adult males (the oestrus) and in their testicles, the testicles and the urine of the stallions being among the largest known sources (Zondek). It is found in very high concentration in the urine of pregnant women after the first two or three months of pregnancy. Over the last months, about 300,000 international units or more are excreted daily. It can also be obtained in large quantities from the pregnant mares' and apes' urines. The human placenta also contains large amounts of oestrogen hormones that are believed to be produced by this organ because during the last months of pregnancy ovariectomized women continue to excrete large amounts of this hormone in the urine [1, 2].

An oestrogenic hormone is also found in the yellow body, in fetal membranes and amniotic fluid, as well as in the adrenal cortex, which was highlighted in a human corial bladder containing a $12.5 \mathrm{~mm}$ long embryo.

\section{Chemistry and terminology}

Doisy, together with his collaborators and Butenandt, isolated from the urine, independently, an oestrogenic hormone in a crystallized form. During the analysis it was found to have the empirical formula $\mathrm{C}_{1} \mathrm{H}_{22} \mathrm{O}_{2}$ and to possess a ketone and a hydroxyl group. Later, Marrian isolated from the urine a second oestrogen compound containing an extra water molecule and having the formula $\mathrm{C}_{18} \mathrm{H}_{24} \mathrm{O}_{3}$. It contains three hydroxyl groups, hence no ketone one [3].

It is less active than the previous form. Dosey gave it the name of -theelin- the first of these oestrogens; other authors

\footnotetext{
*email: alina_calin@hotmail.com; mihaeladebita@yahoo.com; getamitrea@yahoo.com
} 
talk about it calling it ketohydroxyestrin or estrone. The second form, called theelol by Doisy, is also called trihydroxyestrin or estriol; it is converted into estrone by dehydration with potassium bisulfate in vacuum [4].

Oestradiol (dehydroxyestrone, dehydrotheelin) $\left(\mathrm{C}_{18} \mathrm{H}_{24} \mathrm{O}_{2}\right)$ is a third crystallized compound, prepared for the first time in the laboratory by reducing a ketone group of estrone and transforming it into a hydroxyl group. There are three forms of isomerism: alpha, iso and beta. The alpha form is the most active of all three. Since its artificial preparation, alpha-oestradiol has been isolated by MacCorquodale and its collaborators from the ovaries of sows and by Doisy and his co-workers from the urine of pregnant women, so that it is now generally considered to be the true form of the oestrogen hormone, namely oestrogen produced naturally and secreted by the ovary. It is transformed into estrone and estriol in the body. Winterstein and his collaborators isolated beta-from from the urine of pregnant mares. Isoestriol is a synthetic compound and has not been obtained from any natural source. The replacement of the hydroxyl group from the third position of oestradiol by benzoic acid results in a product that has a longer physiological action than the original hormone. This substance-oestradiol benzoate is commercially known under different names. Oestradiol dipropionate and ethinyloestradiol have even more intense and prolonged actions [5, 6]. Emmenin, isolated by Collip and his collaborators from the human placenta, is an estriol ester. It is active buccally. The structural form of the four oestrogen compounds described above is the following: the period immediately before birth contractions, was low, while estriol in active (free) state was much increased. The significance of these data with the activation of the birth mechanism is obvious. Conjugation of estriol with glycuronic acid suggests a neutralizing process in the liver, whereby the uterus is protected from the effect of an excess of circulating oestrogenic hormones [7-9].

Ovarian and testicular hormones belong to the sterol class, being chemically related to bile acids, cholesterol and cholecalciferol. Starting from ergosterol, Marker and his collaborators communicated in 1936 the synthesis of estrone. Other authors synthesized oestradiol from cholesterol. Oestrogenic substances have been obtained from a whole series of sources other than animal tissues and liquids. The synergistic oestrogen compound: 4:4'dehydroxy- $\alpha$ - $\beta$-diethylstilbene, commonly known as diethylstilbestrol, was introduced by Dodds et al. in 1938 and has since been in clinical use. This substance exerts an oestrogenic activity of twice to three times more intense than estrone; its action is reduced by only $60 \%$ when administered by mouth [10].

Other very similar synthetic compounds, also usable in the clinic, are dehydroethylstilbestrol or hexestrol and dienestrol.

The actions of the oestrogen hormone: the main actions of this female hormone are the following: it causes oestrus in animal that have not reached puberty and in ovariectomized adult animals or in normal adult animals during the non-oestrus period: as a result, uterine hypertrophy and proliferation of its glands, vaginal changes,

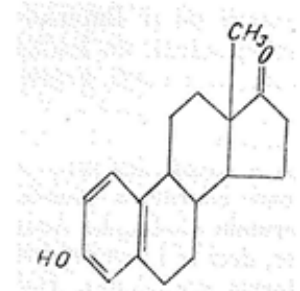

Cetohydroxyestrine (theelin or estrone).

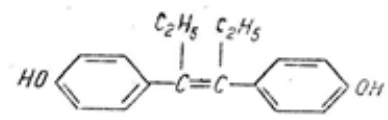

Diethylstilbestrol

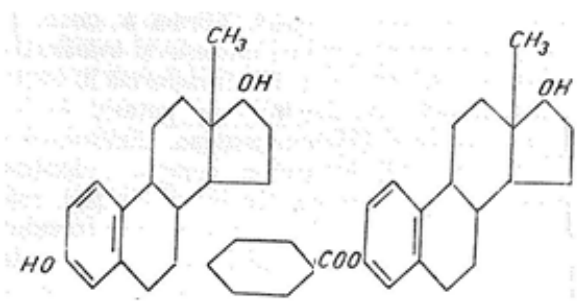

Dihydroxyestrin Oestradiol Benzoate

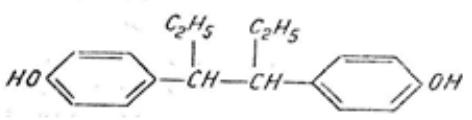

Hexestrol

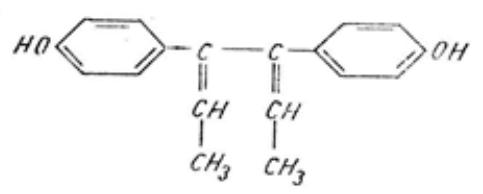

The presence of large amounts of oestrogen hormones in the blood during pregnancy has always been a certain point of confusion in physiology, but Cohen's and Marrian's discovery that estriol is excreted in pregnant urine in a form conjugated to glycuronic acid has brought clarification. This compound - estriol glycuronate is devoid of physiological action, but it is hydrolysed by the usual methods (acidification and heat) used to isolate urinary hormone, thereby releasing active estriol. Moreover, it was found that estriol bound from the urine of women, during

Dienestrol

growth of the mammary glands, rhythmic contraction of the uterine muscle and tubules, psychic and other phenomena related to the oestrus period take place. Prolonged treatment with oestrogen hormones leads to a pronounced hyperplasia of the endometrium, which may be similar to its condition known in the clinic under the name of Schweitzer-like endometrium-; prevents the inevitable atrophy of accessory reproductive organs in ovariectomized animals; it is considered to be responsible 
for the development of secondary sexual characteristics, which in some species represent prominent elements of the mature female. In males, the oestrogen hormone in physiological doses or the endogenous format (testicular oestrogen hormone) appears to synergize with androgenic hormones for the development of secondary sexual characteristics. Prolonged treatment with oestrogenic hormones causes hypertrophy of the fibro-muscular tissues of the prostate, but ithas a weak or null effect on glandular elements. It also stimulates the growth of males' mammary glands. It prevents fertilization of the fertilized egg or causes abortion in the first phase of gestation; induces adrenocortical hypertrophy as it appears to be a result of stimulation of $\mathrm{ACTH}$ release.

This ovarian hormone is thought to account for much of the enormous uterine hyperplasia during pregnancy. It is thought that the oestrogen hormone, which is found in high concentration at the placenta level, can act on the uterine tissue rather locally than through the general circulation. The oestrogen hormone does not stimulate the ovaries; does not exert an appreciable effect on circulation, respiration, basal metabolism or skeletal growth, although prolonged treatment can cause hyperplasia of other extragenital tissues, mitosis in many organs and sometimes multiple fibromyomatous tumours.

Endometrial hyperplasia represents the excessive proliferation and thickening of the uterine mucosa; it is often called glandular hyperplasia because it is characterized by excessive growth of the uterine mucous membranes, as it can capture the entire surface of the uterine mucosa, or only certain parts of it (focal hyperplasia). The main reason for the development of hyperplasia is considered the increase in the level of oestrogens. Significant increases in oestrogen levels in a woman's body are possible in the following situations: treatment with oestrogen-containing medicines (and progesterone-free), during menopause, in women suffering from polycystic ovarian syndrome (POS), in obese women.

Combined oral contraceptives (containing oestrogen and progesterone) do not increase the risk of developing hyperplasia and uterine cancer but even reduce it.

Endometrial hyperplasia is considered a precursor of endometrial cancer.

The oestrogen hormone acts as a preparation for the yellow body hormone (progesterone) and appears to be necessary for maintaining the yellow body during pregnancy.

Prolonged oestrogen treatment increases blood calcium, ovariectomy leads to a loss of water and a decrease in blood volume that can be restored to normal by oestrogen hormone administration [11].

So, the main actions of oestradiol are: it has effects on the mammary gland, the vagina, the endometrium proliferation (maintains the pregnancy with progesterone), the prevention of osteoporosis (involved in bone metabolism), the reduction of cardiovascular risk, the development and maturation of the nervous system.

Oestradiol is primarily produced in the ovary and, during pregnancy, in the placenta. Smaller quantities are produced in the adrenal cortex and the testicle, but also in some peripheral tissues (for example, adipose tissue). Most of this hormone (approximately 98\%) circulates bound to a globulin, called SHBG (sex hormone binding globulin).

The oestradiol level exhibits major variations during the menstrual cycle: it increases during the follicular phase, reaching a maximum level several days before ovulation (when stimulation of FSH and LH secretion starts), after which oestradiol levels decrease moderately during ovulatory phase, then grow again as the yellow body develops (luteal phase).

At menopause, due to decreased ovarian activity, oestradiol levels are low.

The human placenta contains: the two forms of oestrin: estrone (ketohydroxyestrine or theelin). Estrin does not appear in large amounts in urine than at a much later date, and is found in small amounts in the urine of non-pregnant women.

Blood samples of oestrogen show a considerable increase in these with a maximum in the last two months of pregnancy. Blood curve is parallel to that of urinary excretion until birth: at this point, urinary oestrogens decrease, while the massive blood concentration persists. By the colorimetric method, the urinary excretion curves show that oestradiol, oestrone and estriol increase from the luteal phase of the progressive cycle throughout pregnancy to the time when they drop sharply. From the $10^{\text {th }}$ week of pregnancy, estrone and oestradiol excretion increases by 30 times and estriol by 1000 .

It is known that elevated serum levels of Oestradiol and Estriol may lead to dysuria and even hydronephrosis [ 1214]. On the other hand, these substances are used in the medical treatment of endometriosis, because ectopic endometrial tissue has Oestrogen-like receptors (Erkan, 2014) [15].

Estriol appears to be the steroid characteristic of placental function. Increasing estriol excretion in the twin pregnancy shows that hormone production is also dependent on the weight of the organ; decreasing excretion in serious des-pregnancy proves placental failure.

Oestrogen values increase in the blood before labour, and during the dilation period rise sharply [16].

Oestradiol exerts a negative feedback on the hypophysis by progressively decreasing the FSH value. Toward the end of the follicular phase there is a dramatic increase in oestradiol concentration, at which time the feedback becomes positive and produces a secretion marked by FSH and especially LH that will trigger ovulation. After ovulation, the oestradiol level initially shows a marked decrease, but then increases as the yellow body develops. At the end of the menstrual cycle there is a significant decrease in oestrogen levels, pending the initiation of the next follicular phase. The oestrogen level at menopause is generally low due to diminished ovarian production.

In men, oestradiol is produced by testicles and adrenals. Under the conditions of increased fat, an increased level of oestradiol can be recorded, due to the increase in peripheral flavouring of androgens. In men, oestradiol levels may increase in case of excessive marijuana use, alcohol or medical treatments (phenothiazines and spironolactone) $[17,18]$.

Dramatic increases in oestradiol levels can occur in both males and females in germ cell tumours or different gonadal tumours [ 19,20$]$.

\section{Experimental part}

Materials and methods

For the determination of oestradiol, we conducted a study on 64 people, of which 47 women $(73.43 \%)$ and 17 men $(26.57 \%)$.

In men have been reported: fertility disorders, disorders of the hypothalamic-pituitary-gonadal axis, gynecomastia, testicular tumours and adrenocortical hyperplasia.

In women have been reported: fertility disorders, disorders of the hypothalamic-pituitary-gonadal axis, ovarian tumours and adrenocortical hyperplasia. 
The level of oestradiol is routinely used to monitor ovulation during follicular stimulation in patients undergoing treatment for assisted reproductive techniques.

\section{Results and discussions}

The test for oestradiol, the norm of which varies throughout the period, should be strictly granted on the day prescribed by the physician. If the doctor did not specify a specific time interval, the study is performed on day 6 of the period.

Patients will mention the date of the last menstrual period, or the trimester of pregnancy. For the test, the vein blood is collected strictly on an empty stomach, having a vacutainer harvesting vessel without anticoagulant with / without separating gel. It is processed after harvest, the serum is separated by centrifugation, the fresh serum is analysed. If it is not possible to prepare it fresh, the serum is stored at $2-8^{\circ} \mathrm{C}$ or $-20^{\circ} \mathrm{C}$. At least $0.5 \mathrm{~mL}$ serum is required for processing.

If the material is a hemolyzed intense specimen, the sample will be rejected.

Stability of the sample is 2 days at $2-8^{\circ} \mathrm{C} ; 6$ months at $20^{\circ} \mathrm{C}$; do not defrost-re-frost.

The working method is immunochemical with electrochemiluminescence detection (ECLIA).

Reference values are age and gender dependent, and in case of women on menstrual cycle as well, pregnancy respectively.

Table 1

REFERENCE VALUES

\begin{tabular}{|c|c|}
\hline AGE AND GENDER & REFERENCE VALUES (PMOL/L) \\
\hline Women $\cdot$ follicular phase & $45.4-854$ \\
\hline$\cdot$ ovulatory phase & $151-1461$ \\
\hline$\cdot$ luteal phase & $81.9-1251$ \\
\hline$\cdot$ post-menopause & $<18.4-505$ \\
\hline Men & $41.4-159$ \\
\hline Pregnancy $\cdot 1^{\text {st trimester }}$ & $561-11902$ \\
\hline$\cdot 2^{\text {nd }}$ trimester & $5729-78098$ \\
\hline$\cdot 3^{\text {rd }}$ trimester & $31287->110100$ \\
\hline
\end{tabular}

Conversion factors are pmol $/ \mathrm{L} \times 0.273=\mathrm{pg} / \mathrm{mL}(\mathrm{ng} /$ $\mathrm{L}) ; \mathrm{pg} / \mathrm{mL} \times 3.67=\mathrm{pmol} / \mathrm{L} ; \mathrm{pg} / \mathrm{mL}=\mathrm{ng} / \mathrm{L}$ Detection Limit - 18.4pmol / L (5 pg/ mL) ${ }^{5}$.

The oestradiol level exhibits very large fluctuations during the pre-menopause period, during which several determinations will be made using the same method. A comparison of the results obtained by several methods will be avoided due to the large differences between them.

Medicines used: increases: clomiphene, diazepam, decreases: oral contraceptives (inhibits physiological increase), megestrol.

Oestradiol deficiency, as well as excess, can be symptoms of a terrible diseases and can also lead to them, including infertility. High levels of oestradiol, especially when there is a lack of progesterone, lead to endometrial hyperplasia, which may eventually become cancer.

Interference may occur with some components of the kitwhich maylead to inconclusive results: high dose biotin treatment (> $5 \mathrm{mg} /$ day); therefore, it is recommended that blood collection be made at least 8 hours after the last administration; high titers of anti-streptavidin and antiruthenium antibodies.

Hydrophoresis occurring during pregnancy is one of the rare complications of oestrogen physiological hypersecretion in the last trimester of pregnancy (fig. 1).

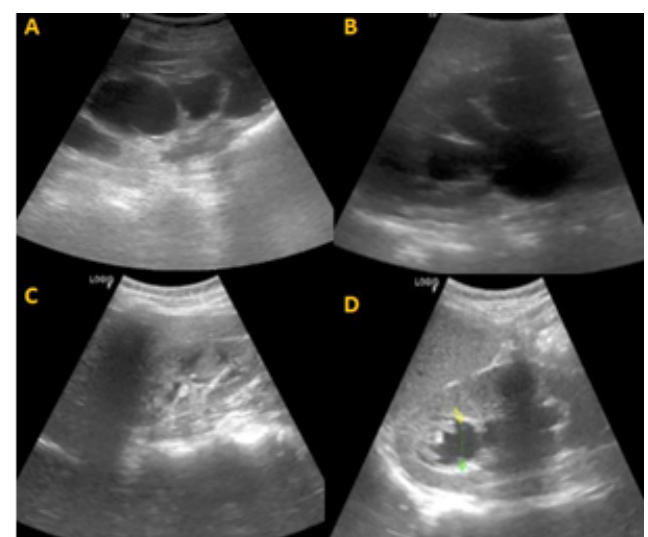

Fig. $1 \mathrm{~A}$ and $\mathrm{B}=$ patients in $10^{\text {th }}$ and $12^{\text {th }}$ week of pregnancy with Oestradiol induced hydronephrosis; $C$ and $D=$ patients in $11^{\text {th }}$ week of pregnancy with Oestradiol induced hydronephrosis and nephrolithiasis

This pathology raises particular treatment difficulties and requires the attention of a complex medical team.

In this situation, the toxic-septic risk on pregnancy is extremely high.

\section{Conclusions}

The main natural oestrogen, oestradiol is formed in the ovary, in the Graff follicle having testosterone as precursor, from which it results by means of the aromatization of the ring $A$ of the steroidal nucleus.

Oestrogens are the main female sex hormones responsible for the development and regulation of female reproductive apparatus and of secondary sexual characteristics.

The cyclical changes in oestrogen and progesterone secretion are due to the pulsatile discharges of the gonadotrophin-gonadotrophin system.

Determinations of serum levels of oestrogenic hormones, both in females and males, play an important prognostic and anticipatory role in the associated gonadal and urinary tract pathology.

\section{References}

1.BARBARISI A, PETILLO 0, DI LIETO A et al. 17 beta oestradiol elicits an autocrine leiomyoma cell proliferation: evidence for a stimulation of protein kinase-dependent pathway. J Cell Physiol, 2001; 186(3): 414

2.RUSU, A.R.G., TARTAU, L.M., STATESCU, C., BOANCA, M., POROCH, V., LUPUSORU, R.V., DIMA, N., BADESCU, C., REZUS, E., REZUS, C., LUPUSORU, C.E., Study of Dynamics of Immunobiochemical Parameters and Pharmacological Interferences in the Metabolic Syndrome. Rev Chim (Bucharest), 69, no.6, 2018, p. 1493-1497

3.VASILCU, TF., STATESCU, C., SASCAU, R., ROCA, M., COSTEA, C.F., ZOTA, M., BARARU, I., CONSTANTIN, M.L., MITU, F. Cardiopulmonary Testing and Biochemical Profile of Coronary Patients Subject to Cardiovascular Recovery Programs. Rev Chim (Bucharest), 69, no.8, 2018, p. 2283-2286.

4.HENRY J OHN BERNARD. Evaluation of endocrine function. In Clinical Diagnosis and Management by Laboratory Methods. ASM Press, USA, 20 Ed., 1998, 336-338.

5.ION TEODORESCU EXARCU. Fiziologia ovarului (Ovary physiology). In Fiziologia oi fiziopatologia sistemului endocrine (Physiology and pathophysiology of the endocrine system) Editura Medicala, Romania, Ed. 1989, 1003-1034
REV.CHIM.(Bucharest) $70 \diamond$ No. 4 2019 
6.ION TEODORESCU EXARCU. Fiziologia ovarului (Ovary physiology). In Fiziologia @i fiziopatologia sistemului endocrine (Physiology and pathophysiology of the endocrine system) Editura Medicalã, Romania Ed. 1989, 1046-1060.

7.CUCIUREANU, D.I., STATESCU, C., SASCAU, R.A., CUCIUREANU, T., CONSTANTINESCU, V.A., HINGANU, D., PREDA, C., HINGANU, M.V., TURLIUC, M,D., Particularities of using contrast agents in diagnosis of stroke. Rev Chim (Bucharest), 70, no. 2, 2019, p. 685-688.

8.J ACQUES WALLACH. Afectiuni endocrine (Endocrine disorders). In Interpretarea testelor de diagnostic (Interpretation of Diagnostic Tests). Editura Stiintelor Medicale, Romania, 7 Ed., 2001, 753-926.

9.TOMA, A.G., SALAHORU P., HINGANU, M.V., HINGANU, D., DIMA COZMA, L. L., PATRASCU, A., GRIGORESCU, C., Rev Chim (Bucharest), 70, no.1, 2019, p. 143

10.*** Laboratory Corporation of America. Directory of Services and Interpretive Guide. Oestradiol. www.labcorp.com 2015. Ref Type: Internet Communication.

11.GRIGORIU, R., CALIN, A.M., ARBUNE,M., MIHALCEANU, E., ONOFRIESCU,M., IONESCU, C., News in the ovarian drilling in the polycystic ovary syndrome, Rev. Chim. (Bucharest), 67, no. 2, 2016, 12.SPRINGER, DA, ALLEN, M, HOFFMAN, V, BRINSTER, L, STAROST, MF, BRYANT, M, ECKHAUS M. Investigation and identification of etiologies involved in the development of acquired hydronephrosis in aged laboratory mice with the use of high-frequency ultrasound imaging. Pathobiol Aging Age Relat Dis. 2014; 4: 10.3402/pba.v4.24932. 13.MINDRUTA IR, BAJENARU OA, PANEA CA, et al. Experience with lacosamide in treating focal epilepsy patients in Romania: efficacy, safety and time to reach response [abstract no. p332]. Epilepsia. 2014;55(Suppl 2):110.
14.CUCIUREANU DI, NITA A, CUCIUREANU A, CUCIUREANU T, CONSTANTINESCU IM. Experience with firstepisode of consciousness loss assessment in a regional center of Romania. [abstract no. p638]. Epilepsia. 2016; 57 (suppl. 2): 194

15.BOANGHER S, MESPOUILLE P, GOFFETTE S, VAN PESCH V, CUCIUREANU D. Herpes simplex encephalitis relapse associated with positive $\mathrm{N}$-methyl-d-aspartate receptor antibodies. ACTA NEUROLOGICA BELGICA; 2018; 118(4): 533-535. DOI: 10.1007/s13760018-0897-9

16.ERKAN EFE, MURAT B, SALIH S, EYUP K, ONDER E, SEFA R. Hormonal Treatment for Severe Hydronephrosis Caused by Bladder Endometriosis. Case Rep Urol. 2014; 2014: 891295.

17.DUCEAC, LD, STAFIE, L, VALEANU, IP, MITREA, G, BACIU, G, BANU, EA, ROMILA, L, LUCA, AC. Sepsis in paediatrics - a special form of infection associated to medical assistance. INTERNATIONAL J OURNAL OF MEDICAL DENTISTRY, 2018, 22(3): 229-235.

18.BOTNARIU, G., POPA, A., MITREA, G., MANOLE, M., PACURA, M., ANGHELE, M., CURIS, C., TEODORESCU, E.. Correlation of Glycemic and Lipid Control Parameters with Cognitive Dysfunction Scores, in Type 2 Diabetic Persons Results from a cross- sectional study. Rev Chim (Bucharest), 69, no. 12, 2018, 3486-3489.

19. LUCA, A.C., DUCEAC, L.D., MITREA, G., CIUHODARU, M.I., ICHIM, D.L., BACIU, G., BANU, E.A., IORDACHE, A.C., Antibiotic Encapsulated Nanomaterials with Application in Medical Area. Mat. Plast., 55, no. 4, 2018, p. 552-554

20.RAFTU, G, MITREA, G, MACOVEI, LA, NECHITA, A. Chemical Additives from the Composition of Plastic Products and Other Materials in Establishing Diagnosis for Alergy Disease. Mat. Plast., 55, no. 4, 2018, p. 609-612.

Manuscript received: 23.09.2018 